\title{
From horse thief to professor: confessions of a plant physiologist
}

\author{
Ulrich Heber
}

Received: 19 January 2012/ Accepted: 3 February 2012/Published online: 8 March 2012

(C) Springer Science+Business Media B.V. 2012

\begin{abstract}
Can 50 years of research, performed between ignorance and the wish to know, and executed between hope, despair, satisfaction and pain, be compressed into an abstract? What has been done in more than 50 years may be expressed in four words: it was worth it. If I had another life, I would do it again. In the beginning of my career, life was an enigma. It still is. Molecular details of the workings of life had been largely unknown when I began. Now, at the end, I still wish to know details: how is light, master of life, manipulated to either support life, when photosynthesis is possible, or to protect it when light endangers it. What is the molecular and the physical nature of the biological mechanisms which control both, energy conservation and energy dissipation, in photosynthesis?
\end{abstract}

Keywords Chlorophyll fluorescence $\cdot$ Desiccation tolerance $\cdot$ Energy conservation · Energy dissipation · Photoprotection · Photosynthesis

When I was asked by my colleague Govindjee to write for Photosynthesis Research a few more personal than scientific lines I hesitated but, after some reflection, I complied. What guided me towards research, towards photosynthesis? The answer, too simple to convince, is naively true: it was curiosity, but, more important, it was the opportunity given to me by others, by my peers, to learn.

This perspective was invited and edited by Govindjee, the Founding Historical Corner Editor of Photosynthesis Research.

\footnotetext{
U. Heber $(\square)$

Julius-von-Sachs-Institute, University of Würzburg,

97082 Würzburg, Germany

e-mail: heber@botanik.uni-wuerzburg.de
}

\section{Saxonian beginnings}

In my life I was much influenced by others although I am, admittedly, a little stubborn, perhaps not easy to influence. Prominent and first in a line of able educators to whom I am indebted was an aunt, Johanna Scheibe, a teacher of biology, who had an independent mind. During the Nazi time she had been suspected of Soviet sympathies and was threatened in her career. Her nickname was 'Red Hanne'. Later, under the Soviet rule, she was fired as director of a High School for her refusal to join a Soviet-German friendship organization. Next I am very grateful to the teachers of the Vitzthum Gymnasium in Dresden, in the free state of Saxony, for 4 years of schooling. 'Non scholae sed vitae discimus': It took me many years to understand that this is not an empty phrase: we really learnt there for life, not for the school which was destroyed in the horrible bombing of the night of February 13/14, 1945. Months later, after the end of the Third Reich, teachers who had survived the Dresden catastrophe were fired by the newly formed so-called anti-fascist administration.

Shortly before the end of the war, the Russian army had occupied the village where the Heber family had owned a farm since several generations. After the chaos left by a clash between German and Russian troops which left two Russian tanks burning behind our farm, property lost its meaning. Since times immemorial, armies had lived from the lands they had occupied. This fate now met the village where I, a 14 year old boy, became a horse thief after our farm had been stripped clean of animals and other possessions. The horse, stolen by a Silesian refugee boy and me, was of Russian or Polish origin. It was joined after some weeks by an ox which my mother had obtained from a Russian soldier in a legally doubtful business exchange after mixing two bottles of vodka and one bottle of water. 
The Russian had insisted on three bottles as the price of the ox. This unequal pair, the horse and the ox, continued my education during the three following years. I learnt much from them. The horse was social, diligent and a little stupid, the ox egotistic, lazy and intelligent. My job was to feed them and to force them to work. That was not easy because the ox was clever. How to be a fair master? What about a combination of carrot and stick? How to balance both? I learnt much for my later life as an academic teacher.

My career as an agricultural worker, officially 'Landwirtschaftsgehilfe', came to an abrupt end when the family was, without compensation, expropriated on November 9, 1948. We were ordered to leave the farm immediately. From my father, an officer in two world wars, drafted in 1939, but now, after his release as a POW, an unpaid agricultural worker on a farm in the British zone of Germany, came the order to go back to formal education. We had been able to warn father that he must not return to the Soviet zone. Obeying his order, I went back to Dresden and finished school within 1 year. In 1949, West Berlin was blockaded by the Soviets. Supplies including coal were flown in from the West. Refugees were flown out. Traffic between the Eastern sector and the Western sectors of Berlin was not yet cut off by the wall. I went to the British sector, registered as a refugee and was flown out in a coal bomber.

\section{Arrival in the West}

In Stolberg, near the Belgian border, as far West as possible, I joined father and found work in the soap company 'Dalli' from which I was transferred after a while to the pharmaceutical company 'Chemie Grünenthal' where I became 'girl for everything'. I cleaned glass tubes, sterilized growth media and transferred conidiospores of Penicillium chrysogenum and cells of Bacillus subtilis, Staphylococcus aureus, Streptococcus pyogenes, and Mycobacterium tuberculosis to nutritious media to make them grow. Safety regulations were still unknown. Knowledge was not required. A little training was sufficient. I was even trusted to sterilize the 50 1, 2001 and 50001 fermenters used for the production of penicillin. I was fascinated by this work. Reading a book titled 'Medizinische Mikrobiologie' made me want to become a microbiologist. The scientific director of the company, Dr. Heinrich Mückter, was a liberal and a fine man. He permitted me to take night shifts to make it possible for me to go by tram to Aachen to the highly reputed Institute of Technology. There, I became a student of Chemistry. At night I was a worker. This life could not be sustained for long. Again Dr. Mückter helped. He had been a student of
Professor Werner Schulemann, Head of the Institute of Pharmacology of the University of Bonn. I went to Bonn.

\section{University of Bonn}

Professor Schulemann employed and, very importantly, paid me as an untrained laborer. My job was to feed and clean the menagerie of rats, mice and canaries the institute held for its malaria and toxoplasmosis research. Now I had time to dig a little into different branches of the natural sciences. I listened to lectures and took part in experimental courses. The physiology of plants, but also the ecology of flowering plants in the beautiful photographs of Professor Walter Schumacher, a late vitalist, fascinated me. In physical chemistry and physics, I understood next to nothing. A course in mathematics required for chemists made me fail miserably. Culprits were cited before Professor Mark von Stackelberg, a physical chemist. He was a Balt who during the first world war had been a Russian officer. Before questioning me in more detail, he asked me kindly what my intentions were. On my answer that my love was really in Botany, and that Chemistry was to keep me in bread, he exclaimed: 'That explains everything!' I was permitted to leave his office in grace. Inorganic chemistry I hated because I was unable to analyze correctly the composition of the salts which were mixed by a misanthropic assistant specially for me, the unfortunate beginner. Returned with an ' $\mathrm{f}$ ' (false) for wrong, an analysis required repetition. A second mistake was not tolerated. For punishment, an extra analysis was given out. How many 'punishment' analyses did I do? Quite a few, it is sad to say. Organic chemistry was pure pleasure. Cooking satisfies me even today. I felt up to it intellectually. Crystallization, when it worked with me, made me feel good, when not, it was at least miraculously produced by the glass rod of Professor Burkhard Helferich, a famous sugar chemist, when he happened to pass by. In 1955, I graduated with the degree 'Diplomchemiker'. One of the examinations that in Physics, shamed me. I was unable to answer any of the questions of Professor Wolfgang Paul, the examiner. I was sent out for discussion between examiner and a witness. When I was called back, I was congratulated. I had received the best note 'Very Good'. Not understanding this apparent misjudgement, I went back to my rats and mice and got very drunk. Much later, when I myself had become an examiner, students possibly profited from this early experience. It had, finally, taught me to be more interested in a student's ability to consider, to ponder, a question that he cannot answer than in his learning. When I met Professor Paul, by then Nobel prize winner, years later at a conference, I told him of my shame. He smiled: 'Have I been wrong in my judgement?' he asked. 
By the time of my graduation, I had intensified my relations to Botany. I had even been permitted to take part in Botanical excursions. The refusal of Professor Walter Schumacher, the botanist, to accept me as his Ph.D. student in the respectable Faculty of Natural Sciences was compensated by the offer of Professor Hermann Ullrich, Institute of Agricultural Botany in the less respectable Faculty of Agriculture, to accept me as paid assistant. What a good luck! My scientific task was to find out why some plants survive freezing and many others do not. My task as assistant was to prepare experiments for demonstration in the lectures of the professor and to operate the slide projector. Experimental failures were not permitted. The demonstration of unfailingly successful experiments in the professorial lectures taught me not to trust appearances. I understood the necessity to look behind surfaces.

The object of my study was winter wheat. Chemistry had taught me to think simply. What was known about frost hardiness? I had read that it comes and goes with the seasons, being low in summer and high in winter. The literature suggested that sugars are important. In Chemistry I had learned that organisms are composed of some classes of compounds. After reading I considered sugars and proteins worth some attention, more than the other constituents. I ground leaves in summer and winter and analyzed the resulting soup as good as I could. This I did diligently for 3 years. I got several publications out of this but not much insight. Still, there was one observation worth following: freezing the soups caused precipitation more in summer than in winter (Ullrich and Heber 1958). There were more sugars in the soup in winter than in summer. Addition of a decent amount of sucrose to the summer soup decreased the precipitation caused by freezing. What sedimented was green. I had read that green chlorophyll is a membrane constituent. Were chloroplast membranes sensitive to freezing? Did sugars protect them? If so, chloroplasts should contain more sugars in winter than in summer. How to show that? Sugars were thought to be mainly localized in the large vacuoles of leaf cells. Known procedures for chloroplast isolation employ aqueous media. Sugars dissolve in them. Visiting libraries, I had come across a short publication describing the isolation of nuclei from freeze-dried liver in an apolar organic solvent. Such solvents do not dissolve sugars. Could I isolate chloroplasts from freeze-dried leaves nonaqueously? It worked. The chloroplasts contained sugars. I published this and the method (Heber 1957) before related (and better) work was done by Ralph Stocking in Davis, California (Stocking 1959). We had been unaware of one another but became friends later editing jointly a volume 'Intracellular Interactions and Transport' in the series 'Encyclopedia of Plant Physiology'.

In 1958 I got the Doctor rerum naturalium (Ph.D.) under Professor Ullrich at the University of Bonn. Two years later I committed an act of brashness. I asked my professor who was a very kind man, to be permitted to submit a thesis for my 'Habilitation', that is to be officially permitted to lecture. This was, of course, immodest, to put it mildly. How to correct this mistake which I came to regret deeply? I went on a tour of Germany to see whether I could find another position. I also wrote a letter to Professor Melvin Calvin, Berkeley, already famous for his photosynthesis work, whether he would accept me as a postdoc. My frost hardiness work had made me realize that I knew nothing about photosynthesis. I received an offer from Professor Dietrich von Denffer, University of Giessen, for a position that included the possibility of habilitation, but also a letter from Professor Calvin: I could come provided I brought support with me. Both improved my standing with Professor Ullrich. I was no longer the lost son. I applied to NATO for a stipend and got it although I neither spoke English nor even proper German. I spoke a disreputable German dialect, Saxon. Professor Ullrich, himself from Saxony, had advised me to take a German language course to learn a decent accent. Many years later, after I had mastered a little English, my British friend David Walker (1937-2012) remarked in a conversation that my language is Anglo-Saxon rather than English.

\section{University of California at Berkeley}

Without being able to swim I decided to jump into the water. I arrived in New York by boat and crossed the continent in a decrepit Chevrolet, which I had bought not yet able to speak a civilized language. After I arrived in the Life Sciences Building of the University of California at Berkeley I was transferred to the care of Roderic Park which meant that I was left to do what I wanted. Calvin I did not see. My desperation was calmed down by the friendliness of Martha Kirk, called mother by the various 'foreigners', by Ning Pon, and by a British postdoc, John Turner. They put me under their wings. Melvin Calvin was interested in Akio Yamamoto, a Japanese postdoc, not in me. The atmosphere in the Berkeley laboratory was simultaneously international and very American. I was intimidated. European education caused me to pay my respects to Dan Arnon, famous for his work on photophosphorylation. Like Calvin, he resided in the LSB (Life Science Building). The audience ended abruptly when I mentioned that I was a postdoc in Calvin's laboratory. No love existed between Arnon and Calvin. Uncertain what I was expected to do, I remembered my non-aqueous chloroplasts. What was called isolated chloroplasts evolved decent amounts of oxygen in the light in the so-called Hill reaction with ferricyanide, but not with $\mathrm{CO}_{2}$. These 'chloroplasts' were in fact membrane systems christened a 
little later 'thylakoids' by Professor Wilhelm Menke at Cologne, Germany (see Menke 1990). During uncareful isolation, chloroplasts rupture losing soluble components. I hoped a combination of these photochemically competent membranes with my non-aqueous and photochemically incompetent chloroplasts, which contained all soluble components, could solve the problem of chloroplast photosynthesis. In fact, it did not, but it at least improved considerably what had already been observed. I got a decent publication together with Inia Tyszkiewicz, a French/Polish postdoc (Heber and Tyszkiewicz 1962). This and work published together with Ning Pon and my wife on the localization of enzymes in chloroplasts (Heber et al. 1963) were the only demonstrable results of 1 year stay with Calvin's group. Other results weighed heavier. I now spoke understandable English. I had gained some confidence. For the first time I had smelled the atmosphere of international science.

\section{Back in Bonn}

After my return to Germany, Professor Ullrich was no longer opposed to my habilitation. I gave the required lecture in a borrowed gown in 1962 and became PrivatDozent (lecturer, no money) and (paid) Oberassistent. This was promotion and demotion simultaneously, because as Oberassistant I became responsible for the administration of the chair. I had less time for scientific work. The institute, ill-equipped in general, was proud to possess a Zeiss spectrophotometer. Kurt Santarius came from Würzburg. We cooperated. One of us took readings every $15 \mathrm{~s}$, the other wrote them down. Results were published in decent international journals, no longer in German as before but now in English (e.g., Santarius and Heber 1965; Heber and Santarius 1965).

In the garden of the institute a lethal nuclear mutant of Vicia faba was found which was green as long as it survived. It proved incapable of photosynthesis (Heber and Gottschalk 1963). I was permitted to talk about this mutant at a photosynthesis meeting held in Gif-sur-Yvette, France. It was my first international conference. After my short presentation, a gentleman approached me saying that Otto Warburg, Nobel prize winner, had expressed the wish to see me. I went with shaking knees. Warburg was very kind: 'Very interesting data, never mind your interpretation, but very interesting'. I was proud.

In Berkeley, I had learnt to handle ${ }^{14} \mathrm{CO}_{2}$. Now I became responsible for the newly established isotope laboratory. This made me a social outcast for some, but increased the respect of others. Even ${ }^{31} \mathrm{P}$ was added to the list of isotopes. I thought that feeding ${ }^{14} \mathrm{CO}_{2}$ to illuminated leaves and looking for the kinetics of labelling inside and outside chloroplasts could give some information on the traffic of photosynthetic products inside leaf cells. The non-aqueous method of chloroplast isolation made this approach possible. Results of my somewhat messy isolation work convinced me that chloroplasts are sites of protein synthesis. This, published in 'Nature', remained my only contribution to this top international journal (Heber 1962). Other results were published with Johannes Willenbrink, a student of Professor Schumacher (Heber and Willenbrink 1964). After a lag-time, the paper caused an uproar. We had published what could not possibly be true. Everybody knew that photosynthesis makes and respiration consumes sugars. Metabolic pathways are opposite in direction. Now our obviously doubtful methods had led us to the untenable conclusion that intermediates such as phosphoglycerate or dihydroxyacetone phosphate, common to both photosynthesis and respiration, travel happily back and forth between chloroplasts and cytosol of intact cells. Moreover, sugars, products of photosynthesis, are not made in the chloroplasts. How could anyone in his right mind publish such nonsense? How could anyone believe it? At a meeting of the German Botanical Society at Munich, I was fiercely attacked by the widely known Professor Otto Kandler and suffered public defeat. I felt devastated. It took time and several persistent publications to substantiate our claims but my German reputation was restored only in 1965 when a publication by David Walker demonstrated unequivocally the rapid transport of phosphoglycerate into and out of isolated chloroplasts (Walker 1965). The prophet is not recognized in his own country. David's paper initiated friendship up to this day between me and David, later head of the Robert Hill Institute of the University of Sheffield. I had my first postdoc in Margret Hudson from Birmingham who helped me to restore my reputation in the battleground of intracellular transport (Urbach et al. 1965).

\section{First visit to the Soviet Union}

Around 1963 I received an unexpected invitation. My frost hardiness papers had been read in the Soviet Union. With Otto Ludwig Lange, later a colleague and now a close friend, I crossed the border between Finland and the Soviet Union by train. Border control increased uneasy feelings. We had entered a different world. The International Cytology Symposium, held at Leningrad, proved to be an almost entirely Russian affair. Hospitality was overwhelming, Russian not understandable. At the Kirow theatre, today Mariinsky theatre, the ballet Lebedinoe Ozero of Tchaikovsky was given for the participants of the symposium. This was beyond anything I had ever seen. I was touched to tears and learnt my first Russian words 'Lishni biljeti' hoping to be understood in my asking for a 
ticket for the sold-out opera in the evenings. Leningrad changed my views of Russia. In comparison, I found Moscow a barbarian city. Later, I learnt to appreciate Moscow as much as Leningrad which today is St. Petersburg.

\section{Frustrated attempts to become a molecular biologist}

In the meantime, the enigma of the genetic code had been broken by Watson and Crick. Nobel prizes were generously distributed in a new field called molecular biology. Photosynthesis had started to look old, even obsolete. Should I not jump? I applied for admission to an international workshop promising introduction into the new methods used in molecular biology. With Kurt Santarius I travelled to Naples only to be bitterly disappointed. We had not come to listen to lectures. We were interested in experiments and experimental demonstrations. Frustration brought us to Capri and Herculaneum. We returned more than ever devoted to photosynthesis.

\section{University of Düsseldorf}

In 1967, I received an offer from Professor Wilfried Stubbe to join him at the newly established University of Düsseldorf as some sort of junior professor. This made bargaining possible. I wanted another year in the United States and got it. The year 1967/68, spent under Director Stacy French at the Carnegie Institution of Washington, Stanford, California (Fig. 1; see Govindjee and Fork 2006), complemented and completed my American education. The working atmosphere differed much from that I had

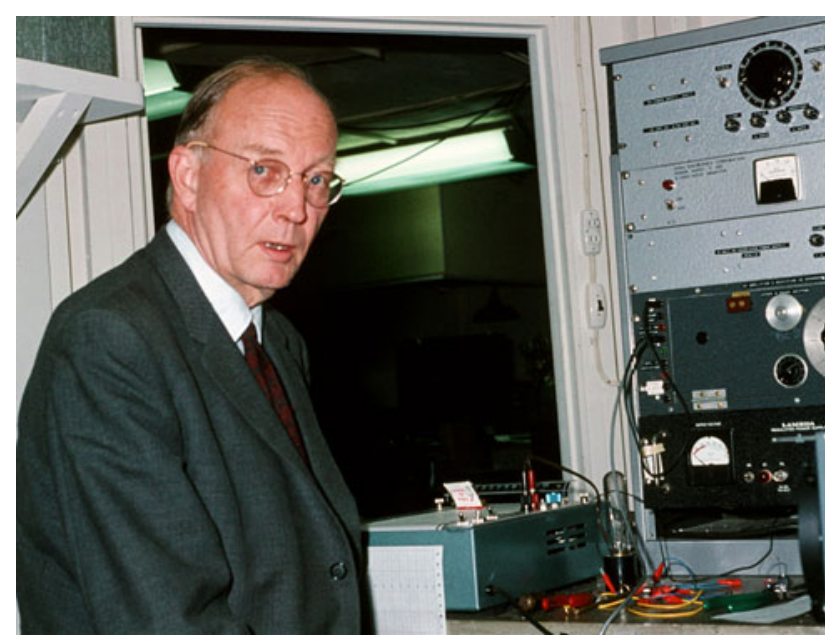

Fig. 1 Stacy French around 1970 at the Department of Plant Biology, Carnegie Institution of Washington, Stanford. Courtesy of Jeanette Brown experienced earlier in Calvin's laboratory. It was no less demanding but decidedly more relaxed. It had a European touch. Under Stacy French I learnt that I had to change my approach to science if I wanted to remain an experimental scientist. To obtain data automatically by using recording equipment is much easier than the laborious work of doing point by point biochemical measurements. However, it needs the acquisition of new skills which I did not possess. I got the message. The recording of light scattering by intact leaves learnt at Stanford required complex interpretation. I concluded that light scattering revealed alterations of leaf energization (Heber 1969). This was not wrong but decades of further research by others were required to open the view on various complex mechanisms which protect leaves against photo-oxidative damage. The molecular basis of these mechanisms is still under investigation.

After I had returned to my new position at Düsseldorf, the problem of establishing a balance between research and teaching was not easy to solve. Martha Kirk, on sabbatical leave from Berkeley, came to my laboratory with her unique combination of human warmth and scientific competence. This was of great help. The teaching load of a professor had to be borne, but how to do this without reducing research? Student unrest also interfered. The slogan of the 1968 student generation was 'Unter den Talaren, der Muff von tausend Jahren' (Below their gowns, the dust of one thousand years! Did they mean me?). I had little objection against student boycott of my lectures but warned, successfully, against interference with my laboratory work. A few postdocs found Düsseldorf attractive. Lina Tyankova from Sofia worked successfully in the frost hardiness field until she decided she had sufficient data and should, before returning to Bulgaria, turn some attention to the elegant shops of Königsallee. Tilberg and Egneus came from Sweden, Umeo Takahama from Kyushu, Japan. He was the first of several Japanese postdocs who were undaunted to do original work in difficult fields (Takahama et al. 1981).

In 1970, I was offered a chair at the Hochschule für Bodenkultur, an Agricultural University in Vienna, Austria. Negotiations proved difficult. A counter-offer kept me in Düsseldorf, now as full professor or 'Ordinarius'. It also made it possible for me to get, as compensation for too much teaching, half a year's time for research with Keith Boardman at the Commonwealth Scientific and Industrial Research Organization, in short CSIRO, in Canberra, Australia. There I met Hal Hatch, famous for his work on C4 photosynthesis (Fig. 2). Keith knew all about cytochromes. I hoped for enlightenment and was not disappointed. But of main importance for me was the presence of Robin Hill (Fig. 3) who with his wife Priscilla was guest of Sir Rutherford (Bob) Robertson, President of the Australian Academy of Sciences. The Hill reaction, 
light-dependent oxygen evolution by chloroplast membranes, was named after Robin who was also responsible for recognizing that two different photo-reactions arranged in sequence make $\mathrm{CO}_{2}$ reduction in photosynthesis possible (see Govindjee and Bjorn 2012 for evolution of this concept). At various conferences, I had admired Robin for his kind innocent questions which, when answered by a speaker, proved to be far less than innocent. They were then pursued with a combination of friendliness and persistence which finally made matters crystal-clear and left the speaker a friend rather than an adversary. Now I met Robin in person. Even now, almost 40 years later, and after meeting the Hills repeatedly in their Cambridge home, I remember my Australian excursions with the Hills and a polish postdoc Stan (Stanislav) to Bateman's bay or to

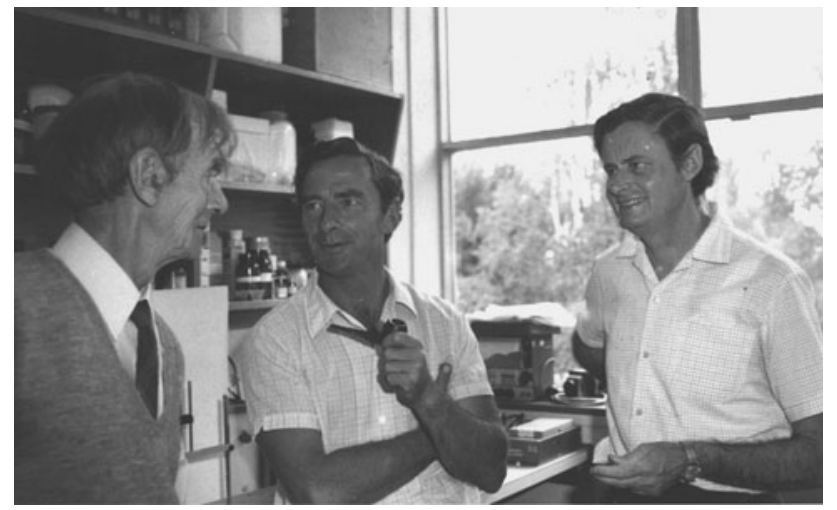

Fig. 2 Keith Boardman (right) in conversation with Hal Hatch (middle) and Robin Hill (left), 1973

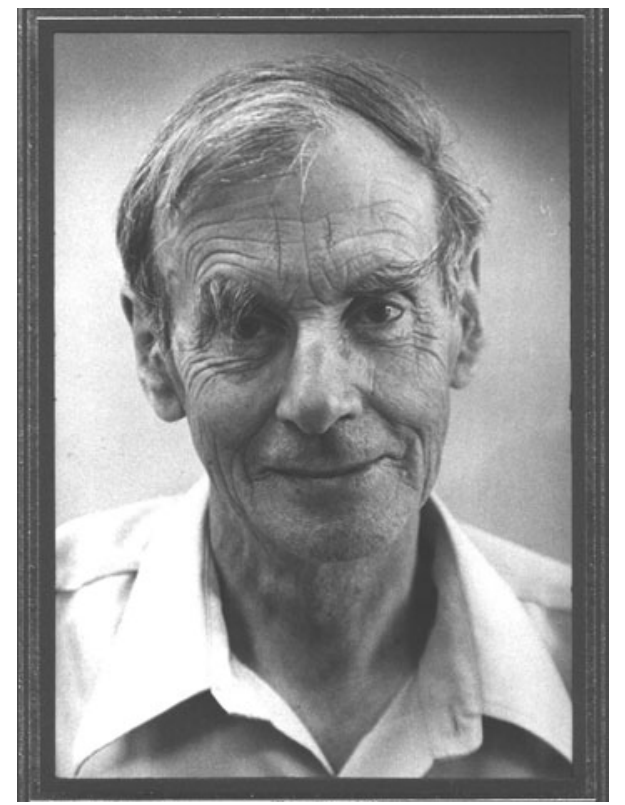

Fig. 3 Robin Hill, University of Cambridge, photo presented to Ulrich Heber by Priscilla Hill, Cambridge
Eucalyptus forests with gratitude and great affection. For the much younger German, the old Englishman proved to be a fountain of broad human wisdom, much beyond photosynthetic wisdom. There were dark nights in which Robin explained the sky of the Southern hemisphere to me.

Back in Düsseldorf, German university life continued along long-established lines. The student revolution had died down. As a main result, I was no longer required to wear a tie. Hans Heldt came from Munich to learn aqueous and non-aqueous techniques of chloroplast isolation. In the biochemical laboratory of Martin Klingenberg he had done work on mitochondrial adenylate transporters. Not much later he demonstrated catalyzed transport across the chloroplast envelope of phospoglycerate and dihydroxyacetone phosphate in exchange against phosphate (Heldt and Rapley 1970) opening the path for brilliant further work on chloroplast transport. Foreign professors came for brief visits. Kursanov from Moscow and Shlyk from Minsk differed from other Soviet visitors. Shlyk remarked he would consider his life well lived if 30 years after his death one line in a textbook would remain that could be traced back to his work. Kursanov impressed me not only by his original work on long-range sugar transport in plants but also by his personality.

When I met Akio Yamamoto again during a visit to Japan, I discussed possibilities for working abroad with him. As an unexpected result, the Japan Society for the Promotion of Science invited me in 1976 to work with Kazuo Shibata (Fig. 4) at the Rikagaku Kenkyusho, the Institute of Physical and Chemical Research (Riken), which is situated in Wako-shi near Tokyo. Kazuo's group worked in an over- crowded laboratory. The professor resided next to it in a very small place together with his secretary, Asayo Suzuki, and with me. At that time, after my American education, I was still a democrat. Now I was suddenly exposed to a hierarchical system. Understanding nothing, I was critical. Nevertheless, relations both to the younger Japanese and to their boss developed well. For the

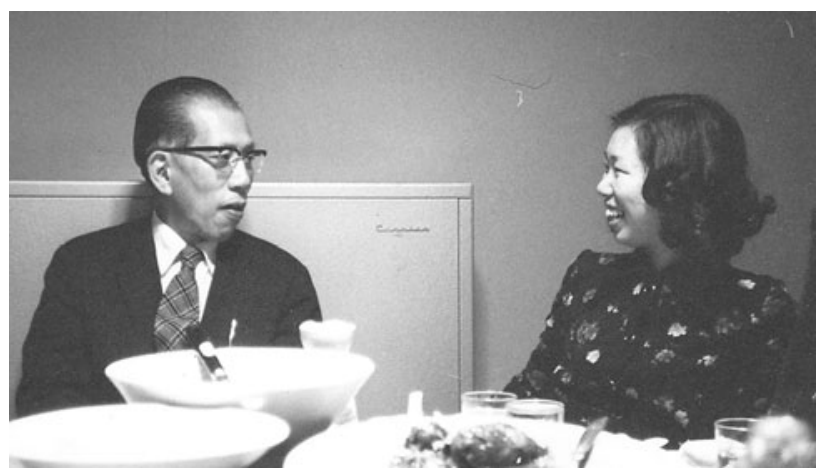

Fig. 4 Kazuo Shibata with Secretary Asayo Suzuki in 1965, courtesy Asayo Iino, Tokyo, formerly Asayo Suzuki 
first time, I felt I could give something to younger scientists. Japanese society impressed me much. What I saw was different from all I had seen in my own country, in the US and in Australia. After the Soviet Union, Japan was another different world. I had some papers with Kazuo Shibata and young Japanese collegues (Inoue et al. 1978; Kobayashi et al. 1979a, b).

Kazuo has my gratitude and my great respect for his tolerance of the foreigner. I had been slow to understand him. When I left, I was, possibly, still a democrat, but subsequent experiences in my own country made me adopt much of what I had learnt in Japan. I had understood that loneliness is often a price to be paid for success. As another result of my Japanese sabbatical, Yoshichika Kobayashi and Tetsuro Mimura came as postdocs to my laboratories in Düsseldorf and later to Würzburg. Kozi Asada came as Humboldt-prize winner. All of the Japanese collegues I had contact with were dedicated scientists, possessed by the Samurai spirit (see e.g., Mimura et al. 1990; Kobayashi and Heber 1995; Asada et al. 1993). They were followed by Chinese postdocs (see e.g., Ye and Heber 1984; Yin et al. 1990; Wu et al. 1991).

\section{University of Würzburg}

In 1978, the possibility arose to make a change once again. I received an offer to go to Würzburg as head of the chair of Botany I of the University. One hundred years earlier, Professor Julius von Sachs had established plant physiology there as an internationally accepted field of botanical research. Otto Lange, which whom I had visited the Soviet Union in 1962, headed the chair of Botany II. He had become a renowned ecologist (Fig. 5). The possibility of co-operation with him influenced my decision. I accepted and left the Rhineland for Frankonia in the North of Bavaria. At the University of Würzburg I remained in a position of C4-Professor and, later, as speaker of a Sonderforschungsbereich (SFB) in which several institutes of biology and chemistry combined their research efforts until I retired officially in 1996. Intermittently, I managed to escape for a time when extended professorial and administrative duties of a large chair threatened to weigh me down. David Walker, by then head of the Robert Hill Institute of the University of Sheffield (Fig. 6), had arranged a Fellowship of the Royal Society which gave me the opportunity to go to Sheffield when life in Würzburg became intolerable. There, I could engage in experimentation. An alternative possibility for escape was provided by Roland Douce and Richard Bligny at the University of Grenoble in France. Work in the French alps led to several papers (Bligny et al. 1997 and other papers). The French university

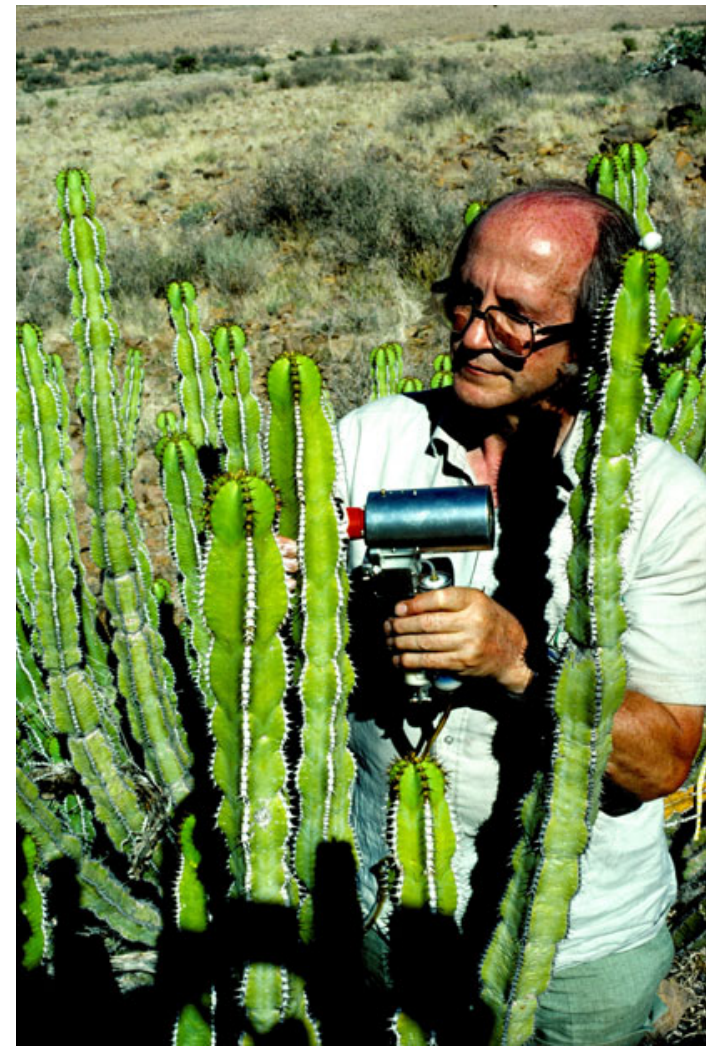

Fig. 5 Otto Ludwig Lange, of Julius von Sachs Institute of Biosciences of the University of Würzburg, in Namibia

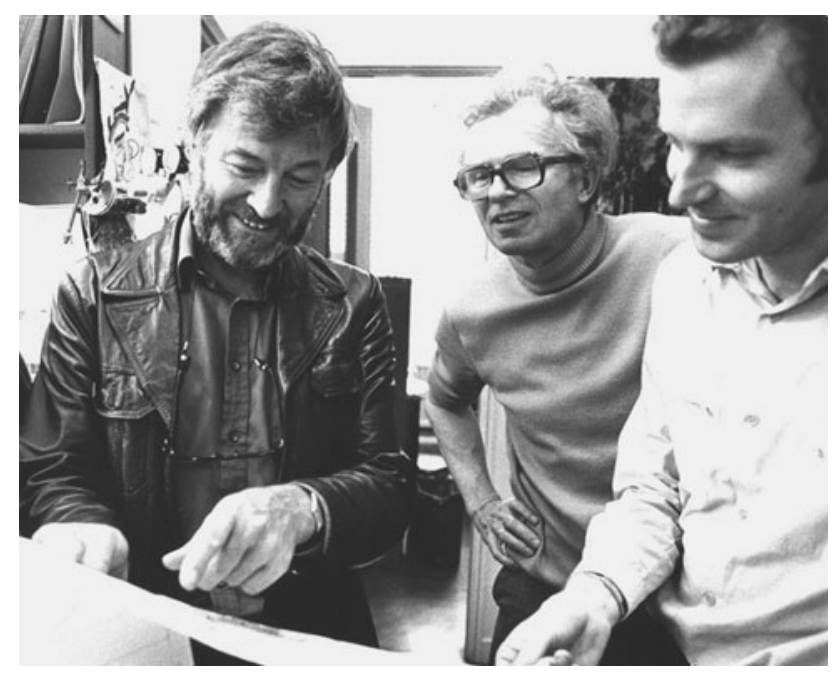

Fig. 6 David Walker, Robert Hill Institute of the University of Sheffield (left) in conversation with the author (middle) and Peter Horton (right) in the late 1980s

possessed a well-equipped alpine ecological station at the Col du Lautaret in the Alps which I could visit for experimental work on mountain plants as often as I wished. 
Absences from the university, prolonged during a sabbatical or more limited, required official permission but in reality were made possible by my coworkers who did my teaching and administrative work while I was away because neither university nor state accepted financial responsibilities for my absences. I am very grateful to my coworkers who paid dearly by additional work for the increased freedom provided by the absence of the boss. Once, while I was away in England, I received a letter of Chancellor Reinhard Günther requesting in no uncertain terms a written explanation for my absence. It was signed by the president. I requested an audience. When I visited the president, he offered me one of his cigars which I, a non-smoker, declined. When I referred to his signature on the letter of complaint the president remarked that he signed many letters without reading them. I left his office not in disgrace. I never wrote the letter of explanation. The system was liberal. It was still a good system. The top of the university supported research. Golden times have always been in the past.

\section{Sabbatical with Kursanov at the Institute of Plant Physiology at Moscow}

In 1985, I was unofficially asked whether I would accept an invitation to the Soviet Union. My affirmative answer brought me as a paid Soviet professor to Moscow where I worked under Akademik (Academician) A.L. Kursanov at the Institute of Plant Physiology of the Soviet Academy of Sciences (Fig. 7). I had known Andrei Lvovich as a formidable scientist. Now I could see him as the director of a large Soviet Academy Institution. In this position he was powerful enough to protect the stubborn Western visitor who had little insight into the complexities of Soviet life. Once I was christened 'Teutonski Knyas' by Academician Adolf Trofimovich Mokronosov, which means knight of the Teutonic Order. This is a doubtful compliment from a Russian because the knights of the Teutonic Order were defeated in 1242 in the famous battle on the frozen Peipus Lake by Russian troops under Alexander Newski. This had stopped German expansion to the East. Kursanov even managed to send me, for my education, out into what Moscovites disapprovingly call 'Glubinka', into the dark provinces of the Soviet Union. Accompanied by a scientist of the institute who had more than one function I was able to visit Academy institutes at Duschanbe in Tadchikistan, at Irkutsk in Siberia, at Pushchino, $200 \mathrm{~km}$ from Moscow, and at Tartu, earlier known as Dorpat, in Estonia. Later I also went to Minsk in Belorussia. Everywhere I met great politeness, but at Pushchino I encountered disbelief. What I said in my lecture was not taken for god's truth. I suggested an experiment next morning to decide right from wrong.

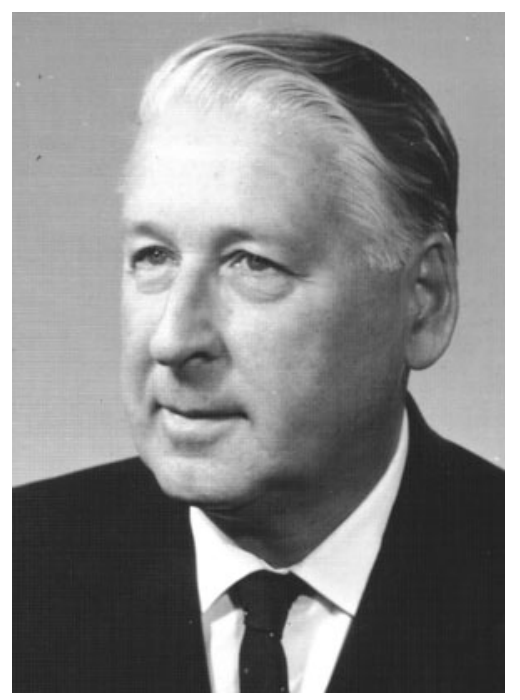

Fig. 7 Andrei Lvovich Kursanov in Moscow, perhaps 1985, courtesy Akademik Vladimir Kuznetsov, Russian Institute of Plant Physiology, Moscow

This was accepted. The experiment led to a joint publication (Klimov et al. 1985) and to very fruitful co-operation with Vladimir Anatolievich Shuvalov, who later became an Academician and head of the Institute of Basic Biological Problems of the Russian Academy of Sciences. German/ Russian cooperation, initiated by these visits, included Academy institutes at Moscow, Pushchino and St. Petersburg and lasted 20 years, up to 2006, when funds had dried up (see e.g., Bukhov et al. 2001; Voitsekhovskaya et al. 2000; Savchenko et al. 2000; Shuvalov and Heber 2003). For a few years, a Belorussian Academy institute at Minsk was also included. At the Institute of Atmospheric Physics of the Estonian Academy of Sciences at Tartu, Agu Laisk was the host. We rapidly discovered common interests and discussed ways how to pursue them. I was much impressed by Estonian inventiveness in solving complex scientific questions in the absence of adequate means. My visit to Estonia was the beginning of many years of co-operation which brought Agu and his collaborator Vello Oja repeatedly to Würzburg and me back to Estonia. (see e.g., Laisk et al. 1989, 1991; Oja et al. 1999).

\section{From Würzburg to Namibia and New Zealand}

After I returned to Würzburg in 1986, three events occured which influenced my subsequent life profoundly although, at the time, I did not understand the relations between them. (1) Together with Otto Lange, I was awarded the Gottfried-Wilhelm-Leibniz Prize of the Deutsche Forschungsgemeinscaft, in short DFG, which gave both of us financial freedom for our research. The prize and the support by the DFG made it possible to invite foreign 
scientists to Würzburg including those I had met in the Soviet Union. (2) At Tchernobyl, a nuclear reactor exploded. (3) Barbara Demmig, a gifted Ph.D. student in my "Chair" and subsequently a coworker of Otto Lange in the neighbouring "Chair", had noticed a consistent relationship between zeaxanthin, a xanthophyll pigment, and protection of plants against oxidative damage by strong light. From this, she proposed a cause/effect relationship (Demmig-Adams 1990). Initially, I did not believe her but slowly, as evidence accumulated, I changed from Saulus to Paulus.

By then, work on spinach which I had started in the 1960s and continued ever since had led me to the immodest opinion that I knew all one needed to know about photosynthesis. This belief was profoundly shaken when Otto Lange took me along to Namibia and later to New Zealand. I was accompanied by fluorescence equipment which had been developed by Ulrich Schreiber in Würzburg (Fig. 8). Lichens were far more prevalent at the foggy coast of Namibia than higher plants. I looked at both. Not unexpectedly, the higher plants of Namibia were similar to spinach in their fluorescence responses. But what about the lichens? And what about mosses which I measured a little later in the French Alps? Their responses confused me. Fluorescence is a signature of photosynthesis (see chapters by Govindjee (2004) and others in Papageorgiou and Govindjee 2004). If I did not understand fluorescence, I had to conclude that I did not understand photosynthesis. I returned to Würzburg in a state of confusion. I started wondering whether my inexplicable Namibian, New Zealand and alpine observations had something to do with my early observations on light scattering by leaves and on photo-protection of plants as seen by Barbara Demmig. Time proved these forethoughts right.

\section{Forest damage}

In the late 1980s, the German public was much worried by alarming reports in the press that our beloved forests were about to die. Polluted air was blamed. I had read in Parkinson's law that it is not the task of the botanist to eradicate the weeds. It is sufficient for him to identify them. I wished to identify the culprits. Sulphur dioxide was a candidate. Being an elected member of Deutsche Akademie der Naturforscher Leopoldina in East Germany, today National Academy of Sciences of the Federal Republic of Germany, I needed a valid visa to visit the German Democratic Republic where forests were dying along the border to Czechoslovakia, now the Czech Republic. Visa was issued for the city of Halle, the site of Leopoldina. Visits to other places were not permitted. Nevertheless, I collected branches of Picea excelsa illegally from trees near the village of my childhood, not far from the border to the Czech state. The analysis of needles from fir trees which 50 years earlier had been property of the Heber family made me admire the tenacity of our trees. High sulphate concentrations in surviving needles were the result of the oxidation of sulphur dioxide, which was emitted by our Czech neighbours, had crossed the border with the socalled Bohemian winds and had entered the needles. Tree death was understandable. Tree survival was the miracle (Kaiser et al. 1993; Elling et al. 2007). $\mathrm{SO}_{2}$ was identified as a culprit. This conclusion was not new. It confirmed conclusions from research work performed about 100 years earlier at Tharandt, next to the village of my childhood, when trees had died in Saxony as industrialization had dramatically increased the burning of sulphur-containing coal. A postdoc, Sonja Veljovic-Iovanovic, doing good
Fig. 8 Fluorescence equipment ready for experimentation near the beach north of Swakopmund, Namibia. In the background brown lichen vegetation (Teloschistes species) and ocean. Courtesy Otto Lange, Würzburg

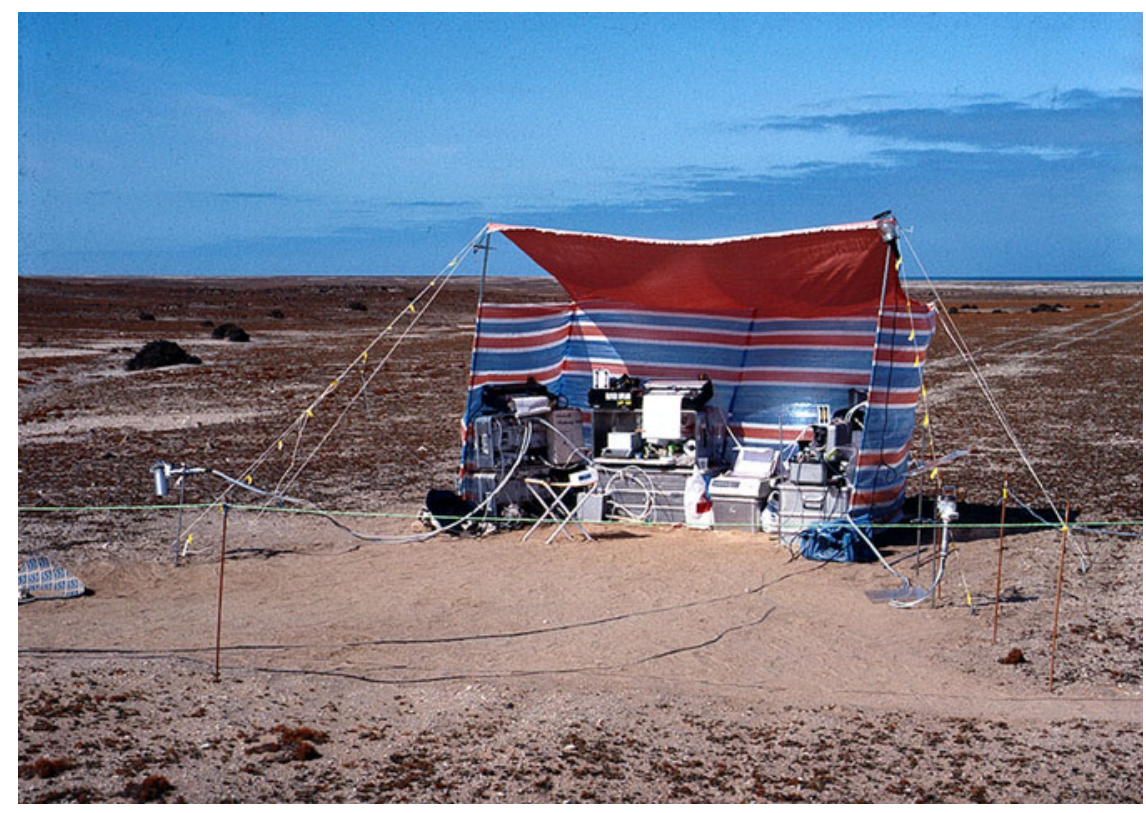


work on $\mathrm{SO}_{2}$ (Veljovic-Jovanovic et al. 1993), did not make my life easier when I protected her, a proud Serbian national, in her private war against German public opinion during the Balkan conflict. Work on forest damage was extended to include ozone which is formed in bright sunshine from a reaction between nitrogen oxide and oxygen (Luwe and Heber 1995). Once again, analytical results made me admire the tenacity of our trees which manage to survive aggressive chemicals which they had never had to encounter in pre-industrialized times.

At Würzburg, Otto Lange initiated co-operation first between our chairs and, later on, also between different research groups within the natural sciences. The first step was the establishment of a Forschergruppe (Research Group), the following step that of a SFB comprising research groups from several institutes of the Faculty of Biology and the Faculty of Chemistry. Cooperation was supported by DFG. After Otto felt he could no longer carry the burdens of being elected speaker of the SFB, I became his successor. By that time, the ideal of a dual responsibility of the university for teaching and research as formulated by Wilhelm von Humboldt at the beginning of the 19th century had lost adherents even in the country of its origin. Political pressures to expand university education had increased. Reforms were demanded not as before from below but now by the political top. Never-ending reform discussions disgusted me. Wishing to end the talking, I volunteered for the position of chairman of the study reform commission and was elected. When I left the room, I overheard one of the colleagues, Roland Benz, say 'Today we have promoted the goat to gardener'. He was right. I arranged only one mammoth session and ignored demands for more. However, the situation made me wonder whether I should not try to go back to research. One possibility was to retire early. I did not wish to help in reducing the university, which in my opinion is 'Die Hohe Schule', the Highest School, of the nation to a status of professional school. In 1996 I retired prematurely, aged 65. As 'Alt-Ordinarius', I would have had three more years in office. I was lucky in that my successor, Professor Rainer Hedrich, permitted me to retain a laboratory in the basement of the institute.

\section{Retirement}

I had now more time for research than ever after graduation. I worked in the laboratory either alone or with established collegues from Eastern countries who came to collaborate with me. Work done since I retired made it even more clear to me than before that I owe much gratitude to Otto Lange for taking me along to Namibia and New Zealand and for his persistent encouragement to look at mosses and lichens, not only at higher plants. In the textbook 'Plant Physiology' by Salisbury I had read an interesting definition of science: 'Science is seeing what everybody has seen, and thinking, what nobody has thought'. What had I seen? A little water added to dry mosses and lichens brought them rapidly back to photosynthetic life. Drying them not only made photosynthesis disappear but also decreased fluorescence. Nevertheless, the organisms remained green although chlorophyll is not a stable pigment. When extracted, it is rapidly destroyed by light. According to the first law of thermodynamics, energy cannot come from nothing and cannot disappear into nothing, but it can be converted from one form into another. How could not only photosynthesis but also fluorescence disappear during drying while the organisms remained green even in strong light? What happens to the energy of light absorbed by chlorophyll when water is absent? Neither can it be kicked back as fluorescence nor can it drive photosynthesis anymore in dry organisms. Why does it not lead to oxidative chlorophyll destruction? Apparently, it is converted into another, harmless form of energy, into heat, before it can do damage. But how? At Tchernobyl, the nuclear reactor had exploded when mechanisms controlling the energy set free during nuclear fission were deactivated during an experiment. Could I tamper with mechanisms which control the energy of absorbed light in dry mosses and lichens? What would happen? A little playing with chemicals showed that dithiothreitol which is known to inhibit zeaxanthindependent photo-protection of higher plants did not inhibit the loss of fluorescence and of photochemical activity during the drying of mosses and lichens whereas glutaraldehyde did. Apparently, this agent which can react with proteins (Coughlan and Schreiber 1984) interfered with the photo-protection of dry lichens and mosses. The inhibition experiments revealed that mechanisms responsible for photo-protection of dry mosses and lichens differ from the zeaxanthin-dependent photo-protection of higher plants. A host of further observations enforced the conclusion that drying activated mechanisms in mosses and lichens which convert the energy of light into heat before light can cause damage. This was not a trivial conclusion because it is known that light used for photosynthesis is converted into redox energy within picoseconds in special reaction centres of the photosynthetic apparatus (Holzwarth et al. 2006). It meant that mechanisms capable of converting the energy of light into thermal energy must be even faster than the mechanisms permitting photosynthesis to occur. This was not easy to publish. Reviewers are sceptical. If unconvinced, they reject publication. When my deductions for which I had no experimental verification finally appeared in print (Heber 2008), a Canadian group had already published picosecond fluorescence measurements of the lichen 
Parmelia sulcata (Veerman et al. 2007) on the basis of a preceding publication by Heber and Shuvalov (2005). Their work revealed a new mechanism of energy dissipation in dry lichens. A Russian coworker, N.K. Bukhov, who had repeatedly worked with me in Würzburg, had brought news of our lichen work including the lichen Parmelia sulcata to Canada. There is much competition in science. It accelerates progress. Fluorescence measurements in the picosecond time scale are at present done with lichens at a Max Planck Institute at Mülheim, Germany and in Nagoya, Japan. Two new mechanisms of photo-protection, one feeding in the antenna of photosystem II excitation energy to dissipation centres which are characterized by weak far-red fluorescence emission (Heber and Shuvalov 2005; Veerman et al. 2007; Komura et al. 2010; Miyake et al. 2011; Slavov et al. 2011; Yamakawa et al. 2012), and the other one dissipating the energy of excitons within the reaction centres themselves (Schweitzer et al. 1998; Heber et al. 2006, 2011; Ivanov et al. 2008; Yamakawa et al. 2012), are presently under active investigation. Work on lichens and mosses is increasing. The field is expanding.

\section{Concluding remarks}

In this contribution I wish to pay tribute to my teachers, most of them internationally known colleagues not from my own country, but I must not forget the role played by a stolen horse and a not legally obtained ox in making me a scientist. As such, I am a Western product, but in what I consider the human outlook of my life I have been strongly influenced by the East, by the worlds of Japan and Russia.

\begin{abstract}
Acknowledgements I wish to express my gratitude to the Deutsche Forschungsgemeinschaft, to the Carnegie Institution of Washington, to the Japan Society for the Promotion of Science, to the Royal Society and to the North Atlantic Treaty Organization (NATO) for support of my research during various times. I also wish to thank the Alexander von Humboldt Foundation for supporting the stays of foreign coworkers and of Humboldt prize winners in my laboratory. My special gratitude is to Govindjee, my respected colleague, for watching me over the years in both the literature and at various conferences, thereby apparently never really despairing, and for finally accepting the risk of letting me present my personal views to the photosynthetic community to whom I am much indebted for accepting me in their midst.
\end{abstract}

\section{References}

Asada K, Heber U, Schreiber U (1993) Electron flow to the intersystem chain from stromal components and cyclic electron flow in maize chloroplasts, as detected in intact leaves by monitoring $\mathrm{P}_{700}$ and chlorophyll fluorescence. Plant Cell Physiol 34:39-50

Bligny R, Gout E, Kaiser W, Heber U, Walker DA, Douce R (1997) $\mathrm{pH}$ regulation in acid-stressed leaves of pea plants grown in the presence of nitrate- or ammonium salts: studies involving 31PNMR spectroscopy and chlorophyll fluorescence. Biochim Biophys Acta 1320:142-152

Bukhov NG, Kopecky J, Pfündel EE, Klughammer C, Heber U (2001) A few molecules of zeaxanthin per reaction centre of pohotosystem II permit effective thermal dissipation of light energy in a poikilohydric moss. Planta 212:739-748

Coughlan SJ, Schreiber U (1984) The differential effects of short-time glutaraldehyde treatments on light-induced thylakoid membrane conformational changes, proton pumping and electron transport properties. Biochim Biophys Acta 767:606-617

Demmig-Adams B (1990) Carotenoids and photoprotection of plants: a role for the xanthophyll zeaxanthin. Biochim Biophys Acta 1020:1-24

Elling W, Heber U, Polle A, Beese F (2007) Schädigung von Waldökosystemen. Auswirkungen anthropogener Umweltveränderungen und schutzmassnahmen. Elsevier GmbH., Spektrum Akademischer Verlag, Heidelberg, p 422. ISBN 978-3-82741765-7

Govindjee (2004) Chlorophyll a fluorescence: a bit of basics and history. In: Papageorgiou G, Govindjee (eds) Chlorophyll a fluorescence: a probe of photosynthesis. Springer, Dordrecht, pp 2-42

Govindjee, Bjorn LO (2012) Dissecting oxygenic photosynthesis: the evolution of the "Z"-scheme for thylakoid reactions. In: Itoh S, Mohanty P, Guruprasad KN (eds) Photosynthesis: overviews of recent progress and future perspective. IK Publishers, New Delhi, pp 1-27

Govindjee, Fork DC (2006) Charles Stacy French (1907-1995). Biographical memoirs, vol 88. National Academy of Sciences, Washington, DC, pp 2-29

Heber U (1957) Zur frage der lokalisation von löslichen zuckern in der pflanzenzelle. Ber Dt Bot Ges 70:371-382

Heber U (1962) Protein synthesis in chloroplasts during photosynthesis. Nature 195:91-92

Heber U (1969) Conformational changes of chloroplasts induced by illumination of leaves in vivo. Biochim Biophys Acta 180: 302-319

Heber U (2008) Photoprotection of green plants: a mechanism of ultra-fast thermal energy dissipation in desiccated lichens. Planta 228:641-650

Heber U, Gottschalk W (1963) On the nature of the genetic block of photosynthesis in a mutant of Vicia faba. Colloq Internat Centre Rech Sci 119:491-498

Heber U, Santarius KA (1965) Compartmentation and reduction of pyridine nucleotides in relation to photosynthesis. Biochim Biophys Acta 100:390-408

Heber U, Shuvalov VA (2005) Photochemical reactions of chlorophyll in dehydrated photosystem II: two chlorophyll forms (680 and $700 \mathrm{~nm}$ ). Photosynth Res 84:85-91

Heber U, Tyszkiewicz E (1962) The rate of photosynthesis in isolated chloroplasts. J Exp Bot 31:185-200

Heber U, Willenbrink J (1964) Sites of synthesis und transport of photosynthetic products within the leaf cell. Biochim Biophys Acta 82:313-324

Heber U, Pon NG, Heber M (1963) Localization of carboxydismutase and triosephosphate dehydrogenase in chloroplasts. Plant Physiol 38:355-360

Heber U, Bilger W, Shuvalov VA (2006) Thermal energy dissipation in reaction centers of photosystem II protects desiccated poikilohydric mosses against photooxidation. J Exp Bot 57:2006-2993

Heber U, Soni V, Strasser RJ (2011) Photoprotection of reaction centers: thermal dissipation of absorbed light energy vs charge separation in lichens. Physiol Plant 142:65-78

Heldt HW, Rapley L (1970) Specific transport of inorganic phosphate, 3-phosphoglycerate and dihydroxyacetone phosphate, and of 
dicarboxylates across the inner membrane of chloroplasts. FEBS Lett 10:143-148

Holzwarth AR, Müller MG, Reus M, Nowazyk M, Saner J, Rogner M (2006) Kinetics and mechanism of electron transfer in intact photosystem II and in the isolated reaction center: pheophytin is the primary electron acceptor. Proc Natl Acad Sci USA 103:6895-6900

Inoue Y, Kobayashi Y, Shibata K, Heber U (1978) Synthesis and hydrolysis of ATP by intact chloroplasts under flash illumination and darkness. Biochim Biophys Acta 504:142-152

Ivanov AG, Sane PV, Hurry V, Öquist G, Huner NPA (2008) Photosystem II reaction center quenching: mechanisms and physiological role. Photosynth Res 98:565-574

Kaiser W, Dittrich A, Heber U (1993) Sulfate concentrations in Norway spruce needles in relation to atmospheric $\mathrm{SO}_{2}$ : a comparison of trees from various forests in Germany with trees fumigated with $\mathrm{SO}_{2}$ in growth chambers. Tree Physiol 12:1-13

Klimov VV, Shuvalov VA, Heber U (1985) Photoreduction of pheophytin as a result of electron donation from the watersplitting system to photosystem-II reaction centers. Biochim Biophys Acta 809:345-350

Kobayashi Y, Heber U (1995) $\mathrm{H}^{+} / \mathrm{e}$ is three during steady state linear electron transport to low-potential acceptors and intact chloroplasts, but two with ferricyanide in thylakoids. Plant Cell Physiol 36:1629-1638

Kobayashi Y, Inoue Y, Furuya F, Shibata K, Heber U (1979a) Regulation of adenylate levels in intact spinach chloroplasts. Planta 147:69-75

Kobayashi Y, Inoue Y, Shibata K, Heber U (1979b) Control of electron flow in intact chloroplasts by the intra thylakoid $\mathrm{pH}$, not by the phosphorylation potential. Planta 146:481-486

Komura M, Yamagishi A, Shibata Y, Iwasaki I, Itoh S (2010) Mechanism of strong quenching of photosystem II chlorophyll fluorescence under drought stress in a lichen, Physciella melanchla, studied by subpicosecond fluorescence spectroscopy. Biochim Biophys Acta 1797:331-338

Laisk A, Lange OL, Heber U (1989) Air pollution and forest decline. In: Proceedings of international conference. Airborne particles and their negative effects on the cultural heritage, the environment and man. Ravello, pp 195-206 (publ. in PACT 33-III.I, 1991)

Laisk A, Kiirats O, Oja V, Gerst U, Weis E, Heber U (1991) Analysis of oxygen evolution during photosynthetic induction and in multiple-turnover flashes in sunflower leaves. Planta 186: 434-441

Luwe M, Heber U (1995) Ozone detoxification in the apoplast and symplast of spinach, broad bean and beech leaves at ambient and elevated concentrations of ozone in air. Planta 107:448-455

Menke W (1990) Retrospective of a botanist. Photosynth Res 25: $77-82$

Mimura T, Dietz KJ, Kaiser W, Schramm MJ, Kaiser G, Heber U (1990) Phosphate transport across biomembranes and cytosolic phosphate homeostasis in barley leaves. Planta 180:139-146

Miyake H, Komura M, Itoh S, Kosugi M, Kashino Y, Satoh K, Shibata Y (2011) Multiple dissipation components of excess light energy in dry lichen revealed by ultrafast fluorescence study at $5 \mathrm{~K}$. Photosynth Res 110:39-48

Oja V, Savchenko G, Jakob B, Heber U (1999) pH and buffer capacities of apoplatic and cytoplasmic cell compartments in leaves. Planta 209:239-249
Papageorgiou, Govindjee (eds) (2004) Chlorophyll a fluorescence: a probe of photosynthesis. Springer, Dordrecht

Santarius KA, Heber U (1965) Changes in the intracellular levels of ATP, ADP, AMP und $\mathrm{P}_{\mathrm{i}}$ and regulatory function of the adenylate system in leaf cells during photosynthesis. Biochim Biophys Acta 100:39-54

Savchenko G, Wiese C, Neimanis S, Hedrich R, Heber U (2000) pH regulation in apoplastic and cytoplasmic cell compartments of leaves. Planta 211:246-255

Schweitzer RH, Melkozernov AN, Blankenship RE, Brudvig GE (1998) Time-resolved fluorescence measurements of photosystem II: the effect of quenching by oxidized chlorophyll Z. J Phys Chem B 114:8320-8326

Shuvalov VA, Heber U (2003) Photochemical reactions in dehydrated photosynthetic organisms, leaves, chloroplasts and photosystem II particles: reversible reduction of pheophytin and chlorophyll and oxidation of $\beta$-carotene. Chem Phys 294:227-237

Slavov C, Reus M, Holzwarth AR (2011) Two different mechanisms cooperate in the desiccation-induced excited state quenching in Parmelia lichen. International workshop "mechanism s of nonphotochemical quenching”, Passau, p. 46

Stocking CR (1959) Chloroplast isolation in non-aqueous media. Plant Physiol 34:56-61

Takahama U, Shimizu-Takahama M, Heber U (1981) The redox state of the NADP system in illuminated chloroplasts. Biochim Biophys Acta 637:530-539

Ullrich H, Heber U (1958) Über das denaturieren pflanzlicher eiweisse durch ausfrieren und seine verhinderung. Planta 51:399-413

Urbach W, Hudson MA, Ullrich W, Santarius KA, Heber U (1965) Verteilung und wanderung von phosphoglycerat zwischen den chloroplasten und dem cytoplasma während der photosynthese. Z Naturforschg 20b:890-898

Veerman J, Vasil'ev S, Paton GD, Ramanauskas J, Bruce D (2007) Photoprotection in the lichen Parmelia sulcata: the origins of desiccation-induced fluorescence quenching. Plant Physiol 145:997-1005

Veljovic-Jovanovic S, Bilger W, Heber U (1993) Inhibition of photosynthesis, stimulation of zeaxanthin formation and acidification in leaves by $\mathrm{SO}_{2}$ and reversal of these effects. Planta 191:365-376

Voitsekhovskaya O, Pakhomova MV, Syutkina AV, Gamalei YV, Heber U (2000) Compartmentation of assimilate fluxes in leaves II. Apoplastic sugar levels in leaves of plants with different companion cell types. Plant Biol 2:107-112

Walker DA (1965) Correlations between photosynthetic activity and membrane activity in isolated chloroplasts. Plant Physiol 40:1157-1161

Wu J, Neimanis S, Heber U (1991) Photorespiration is more effective than the Mehler reaction to protect the photosynthetic apparatus against photo inhibition. Bot Acta 104:283-291

Yamakawa H, Fukushima Y, Itoh S, Heber U (2012) Three different mechanisms of energy dissipation of a desiccation-tolerant moss serve one common purpose: to protect reaction centres against photo-oxidation. J Exp Bot (in press)

Ye J-Y, Heber U (1984) Inhibition of photosynthetic reactions by aureomycin. Z Naturforschg 39c:627-633

Yin Z-H, Neimanis S, Wagner U, Heber U (1990) Light-dependent $\mathrm{pH}$ changes in leaves of $\mathrm{C}_{3}$ plants. I. Recording $\mathrm{pH}$ changes in different cellular compartments by fluorescent probes. Planta 182:244-252 